\title{
Article \\ Effects of Exogenous Application of Indole-3-Butyric Acid on Maize Plants Cultivated in the Presence or Absence of Cadmium
}

\author{
Kristína Šípošová ${ }^{1} \mathbb{D}$, Eva Labancová ${ }^{2} \mathbb{D}$, Danica Kučerová ${ }^{2}$, Karin Kollárová ${ }^{2}$ (D) and Zuzana Vivodová ${ }^{2, *}(\mathbb{D}$ \\ 1 Institute of Botany, Plant Science and Biodiversity Centre, Slovak Academy of Sciences, Dúbravská cesta 9, \\ 84523 Bratislava, Slovakia; kristina.siposova@savba.sk \\ 2 Institute of Chemistry, Slovak Academy of Sciences, Dúbravská cesta 9, 84538 Bratislava, Slovakia; \\ eva.labancova@savba.sk (E.L.); danica.kucerova@savba.sk (D.K.); karin.kollarova@savba.sk (K.K.) \\ * Correspondence: zuzana.vivodova@savba.sk
}

\section{check for}

updates

Citation: Šípošová, K.; Labancová, E.; Kučerová, D.; Kollárová, K.; Vivodová, Z. Effects of Exogenous Application of Indole-3-Butyric Acid on Maize Plants Cultivated in the Presence or Absence of Cadmium. Plants 2021, 10, 2503. https:// doi.org/10.3390/plants10112503

Academic Editors: Pirjo Mäkelä,

Mercè Llugany, Peter A. Roussos and Mumtaz Cheema

Received: 26 October 2021

Accepted: 17 November 2021

Published: 18 November 2021

Publisher's Note: MDPI stays neutral with regard to jurisdictional claims in published maps and institutional affiliations.

Copyright: (c) 2021 by the authors. Licensee MDPI, Basel, Switzerland. This article is an open access article distributed under the terms and conditions of the Creative Commons Attribution (CC BY) license (https:/ / creativecommons.org/licenses/by/ $4.0 /)$.

\begin{abstract}
Auxins are plant hormones that affect plant growth, development, and improve a plant's tolerance to stress. In this study, we found that the application of indole-3-butyric acid (IBA) had diverse effects on the growth of maize (Zea mays L.) roots treated without/with Cd. IBA caused changes in the growth and morphology of the roots under non-stress conditions; hence, we were able to select two concentrations of IBA $\left(10^{-11} \mathrm{M}\right.$ as stimulatory and $10^{-7} \mathrm{M}$ as inhibitory). IBA in stimulatory concentration did not affect the concentration of $\mathrm{H}_{2} \mathrm{O}_{2}$ or the activity of antioxidant enzymes while IBA in inhibitory concentration increased only the concentration of $\mathrm{H}_{2} \mathrm{O}_{2}(40.6 \%)$. The application of IBA also affected the concentrations of mineral nutrients. IBA in stimulatory concentration increased the concentration of $\mathrm{N}, \mathrm{K}, \mathrm{Ca}, \mathrm{S}$, and $\mathrm{Zn}$ (5.8-14.8\%) and in inhibitory concentration decreased concentration of $\mathrm{P}, \mathrm{K}, \mathrm{Ca}, \mathrm{S}, \mathrm{Fe}, \mathrm{Mn}, \mathrm{Zn}$, and $\mathrm{Cu}$ (5.5-36.6\%). Moreover, IBA in the concentration $10^{-9} \mathrm{M}$ had the most positive effects on the plants cultivated with $\mathrm{Cd}$. It decreased the concentration of $\mathrm{H}_{2} \mathrm{O}_{2}(34.3 \%)$, the activity of antioxidant enzymes (23.7-36.4\%), and increased the concentration of all followed elements, except $\mathrm{Mg}$ (5.5-34.1\%), when compared to the $\mathrm{Cd}$.
\end{abstract}

Keywords: antioxidant enzymes; auxin; growth; indole-3-butyric acid; maize; nutrients; reactive oxygen species

\section{Introduction}

Auxins are a group of plant hormones that affect and control many metabolic processes, including plant growth and responses to the environment [1]. Biosynthesis, polar transport, and the generation of auxin maxima play key roles in the coordination of the plant's growth. The crosstalk between auxins and other substances, e.g., ethylene, cytokinins, gibberellin, is also an important part of the regulation of auxin production and transport in plants [2]. The crosstalk between auxins and reactive oxygen species (ROS) is integrated into a complex hormonal network that controls diverse aspects of plant growth and development [1].

ROS, such as superoxide radicals, hydrogen peroxide, singlet oxygen, and hydroxyl radicals, are present in every plant cell because they are continuously produced as unwanted by-products of various metabolic pathways, which are mainly localized in mitochondria, chloroplasts, and nitrogen-fixing nodules [3-5]. However, the concentrations of ROS are controlled, reduced, and scavenged by antioxidant enzymes [3,4]. Superoxide is converted to hydrogen peroxide $\left(\mathrm{H}_{2} \mathrm{O}_{2}\right)$ and oxygen $\left(\mathrm{O}_{2}\right)$ by superoxide dismutase (SOD, EC 1.15.1.1), and then $\mathrm{H}_{2} \mathrm{O}_{2}$ is converted to water $\left(\mathrm{H}_{2} \mathrm{O}\right)$ and $\mathrm{O}_{2}$ by ascorbate peroxidase (APX, EC 1.11.1.11), guaiacol peroxidase (EC 1.11.1.7), catalase (CAT, EC 1.11.1.6), and glutathione reductase (EC 1.8.1.7) [4,5]. All types of ROS are involved in the networks of signaling pathways and in the responses to environmental factors [3,4].

Cadmium $(\mathrm{Cd})$ belongs to a group of environmental stress factors and is toxic not only for the plant but also for all living organisms [6-8]. The concentration of $\mathrm{Cd}$ in the 
environment in the last decade is increasing exponentially, mainly due to contaminated sewage sludge and wastewater leakage, or due to landfills [9]. Even the low concentration of $\mathrm{Cd}$ in the environment can be easily transferred from contaminated soils to plants, and enhanced accumulation of $\mathrm{Cd}^{2+}$ in the tissues poses a great risk to all living organisms through the food chain [10]. Once absorbed, $\mathrm{Cd}$ is retained in the human body and is toxic to the kidney, respiratory and digestive systems, and can cause bone demineralization and other diseases [11]. Exogenously applied auxins can alleviate Cd toxicity [12], but the mechanisms of their action are still not fully understood.

Bashri and Prasad [12] found that indole-3-acetic acid (IAA) increases the activity of the ascorbate-glutathione cycle. Similar results were also observed by Khan et al. [13] in their study, where the exogenous application of IAA stimulated the level of ascorbate and the activity of the ascorbate-glutathione cycle which enhanced the ability of tomato seedlings to counter the $\mathrm{Cd}$-induced oxidative stress. Therefore, this may indicate the regulatory role of IAA in the ascorbate-glutathione cycle that may contribute to $\mathrm{Cd}$ alleviation. On the other hand, Demecsová et al. [14] found that IBA induces a high production of nitric oxide (NO) which effectively reduces high levels of superoxide via the formation of peroxynitrite $\left(\mathrm{ONOO}^{-}\right)$. One of the pathways of NO production during IBA treatment is due to the conversion of IBA to IAA. For instance, Piacentini et al. [15] found that the application of IBA on Cd stressed rice effectively supplemented the NO levels in roots which had plummeted due to $\mathrm{Cd}$ toxicity. The hypothesis suggests that exogenously applied auxin is likely involved in several ways leading to the alleviation of toxicity.

As mentioned above, $\mathrm{Cd}$ decreases the uptake and accumulation of nutrients, which results in decreased plant biomass. One of the possible actions of auxins might be via an improved uptake of nutrients; however, little is known about the effects of exogenously applied auxins on the nutrient status of plants growing in both contaminated and noncontaminated conditions. Many studies focused on the effects of IAA—natural auxin-on the antioxidant defense system and mineral nutrients, with/without the presence of toxic metals [12,16,17]. However, IAA is not suitable as a component of fertilizers because it has low stability in solution and quickly degrades [18]. Furthermore, only one or a non-specified concentration of auxin was used in available studies [12,16,17].

The aims of this study were to investigate the effects of the exogenously applied auxin indole-3-butyric acid (IBA) on the morphology and physiology of maize (Zea mays L.) plants cultivated with or without $\mathrm{Cd}$. Maize is a staple food that is grown and distributed worldwide. It is grown on different soils around the world including those that are contaminated with toxic elements. For that reason, it is necessary to study the methods that could improve the growth and quality of this crop. In our experiments, we determined the concentration of $\mathrm{H}_{2} \mathrm{O}_{2}$, the activity of antioxidant enzymes, and the changes in the uptake of mineral nutrients in these treatments: two IBA concentrations with different effects on the growth of the maize roots cultivated without $\mathrm{Cd}, \mathrm{Cd}$ treatment, and one stimulatory concentration of IBA in the presence of $\mathrm{Cd}$.

We chose IBA because it has higher stability in the solution than IAA [18]. IBA in the aqueous solution retains its stability for more than 28 days [19], while IAA disintegrates in the solution after 2 days. Stability of IBA depends on many factors such as oxygen level or exposure to the heat and light. IBA in the combination with alkylated choline cations is much more stable and may be suitable as fertilizer [20].

Plants were cultivated hydroponically during whole experiments. This type of cultivation allows a better examination of the root system but its disadvantages are abnormal root conditions [21]. Roots had not only different morphological properties (length, root hairs) but also anatomical (development of apoplasmic barriers), compared to the roots grown in the soil [22]. 


\section{Results}

2.1. Effects of IBA on the Growth Parameters in the Absence and Presence of $C d$

We tested the effects of IBA in different concentrations (range from $10^{-12} \mathrm{M}$ to $10^{-7} \mathrm{M}$ ) and determined their effects on the growth parameters (Figure 1).

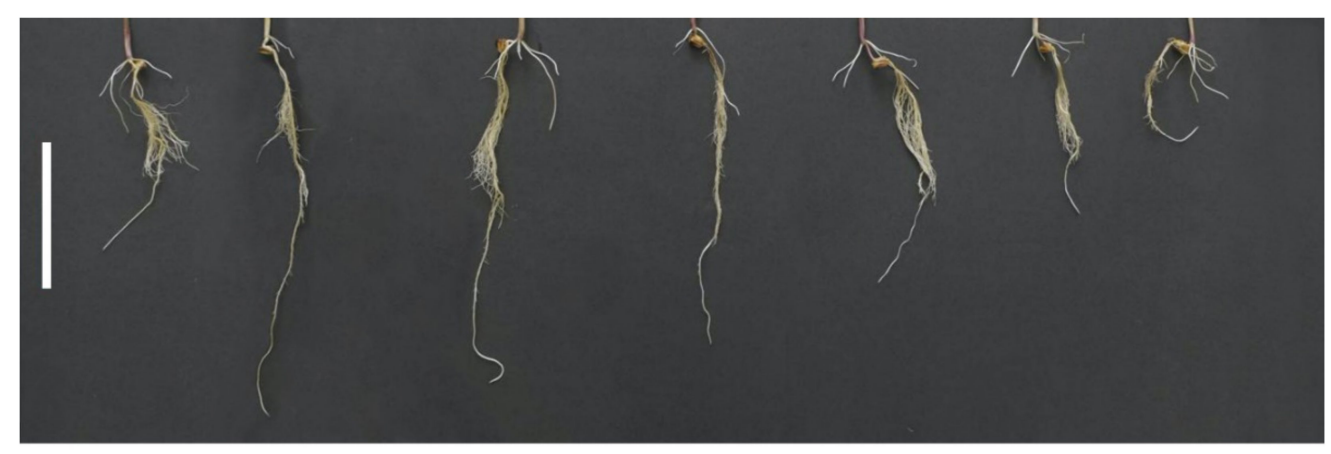

Control $10^{-12} \mathrm{M}$ IBA $10^{-11} \mathrm{M}$ IBA $10^{-10} \mathrm{M}$ IBA $10^{-9} \mathrm{M}$ IBA $10^{-8} \mathrm{M}$ IBA $10^{-7} \mathrm{M}$ IBA

Figure 1. The effects of IBA on the root morphology of plants. Scale bar is $10 \mathrm{~cm}$.

IBA in concentrations of $10^{-12} \mathrm{M}, 10^{-11} \mathrm{M}, 10^{-10} \mathrm{M}$ stimulated root growth compared to the control (Figure 2). The elongation of PR increased with decreasing auxin concentration $\left(10^{-10} \mathrm{M}-27.0 \% ; 10^{-11} \mathrm{M}-60.7 \% ; 10^{-12} \mathrm{M}-75.6 \%\right)$ (Figure 2a), and the strongest increase in PR branching (the length of the branched part of the PR) was found in those plants treated with $10^{-12} \mathrm{M}, 10^{-11} \mathrm{M}, 10^{-10} \mathrm{M}$ (by $13.5 \%, 13.8 \%, 12.6 \%$, respectively) (Figure $2 \mathrm{~b}$ ). The concentration $10^{-9} \mathrm{M}$ had only a small stimulatory effect on root branching (by $8.2 \%$ ). IBA also affected the number of LR. The highest number of LR was determined in the plants treated with IBA in concentrations of $10^{-11} \mathrm{M}$ (by $83.2 \%$ ), $10^{-12} \mathrm{M}$ (by $68.8 \%$ ), and $10^{-10} \mathrm{M}$ (by 64.0\%), compared to the control (Figure 2c). Similar to the root branching, IBA in a concentration of $10^{-9} \mathrm{M}$ stimulated the formation of LR only slightly (by $21.9 \%$ ). Even though, the application of IBA in stimulatory concentrations $\left(10^{-12}, 10^{-11}, 10^{-10}, 10^{-9} \mathrm{M}\right)$ positively influenced the growth of the maize roots, only the $10^{-11} \mathrm{M}$ concentration increased the FW of the roots significantly (by 28.8\%) and none of the concentrations affected their DW to any great extent. IBA in the $10^{-8} \mathrm{M}$ concentration had minimal effects on the growth parameters (Figure $2 \mathrm{~d}, \mathrm{e}$ ). IBA in the $10^{-7} \mathrm{M}$ concentration negatively affected plant growth: inhibited the elongation of PR (by 73.2\%), decreased the number of LR (by $34.5 \%$ ), FW, and DW (by about $27 \%$ ) compared to the control. In the light of these results, we selected two concentrations of IBA that had different effects on root growth: $10^{-11} \mathrm{M}$ as stimulatory and $10^{-7} \mathrm{M}$ as inhibitory.

We ascertained that $\mathrm{Cd}$ in the $50 \mu \mathrm{M}$ concentration in the substrate negatively affected plant growth (Figure 3). Cd strongly inhibited elongation of PR (by 60.8\%), decreased the number of LR (by 52.1\%), FW (by $48.8 \%$ ), and DW (by $46.3 \%$ ), when compared to the control (Figure 4). However, Cd stimulated branching of the PR (by 8.1\%).

We tested the effects of IBA in the same concentrations as above (ranging from $10^{-12} \mathrm{M}$ to $10^{-7} \mathrm{M}$ ) on plants growing in the presence of $\mathrm{Cd}$ (Figure 4). Contrary to the non-stress conditions, IBA in the $10^{-9} \mathrm{M}$ concentration had the most significant stimulatory effects on plants under Cd stress (Figure 4). IBA in this concentration stimulated the elongation of PR (by 31.8\%) (Figure 4a), the number of LR (by 30.7\%) (Figure 4c), and both FW (by 52.1\%) and DW (by 57.8\%) (Figure 4d,e), compared to the Cd treatment. Concentrations that were lower or higher than $10^{-9} \mathrm{M}$ did not significantly positively affect plant growth and we concluded that these concentrations were not suitable to be efficient in the alleviation of Cd toxicity. 


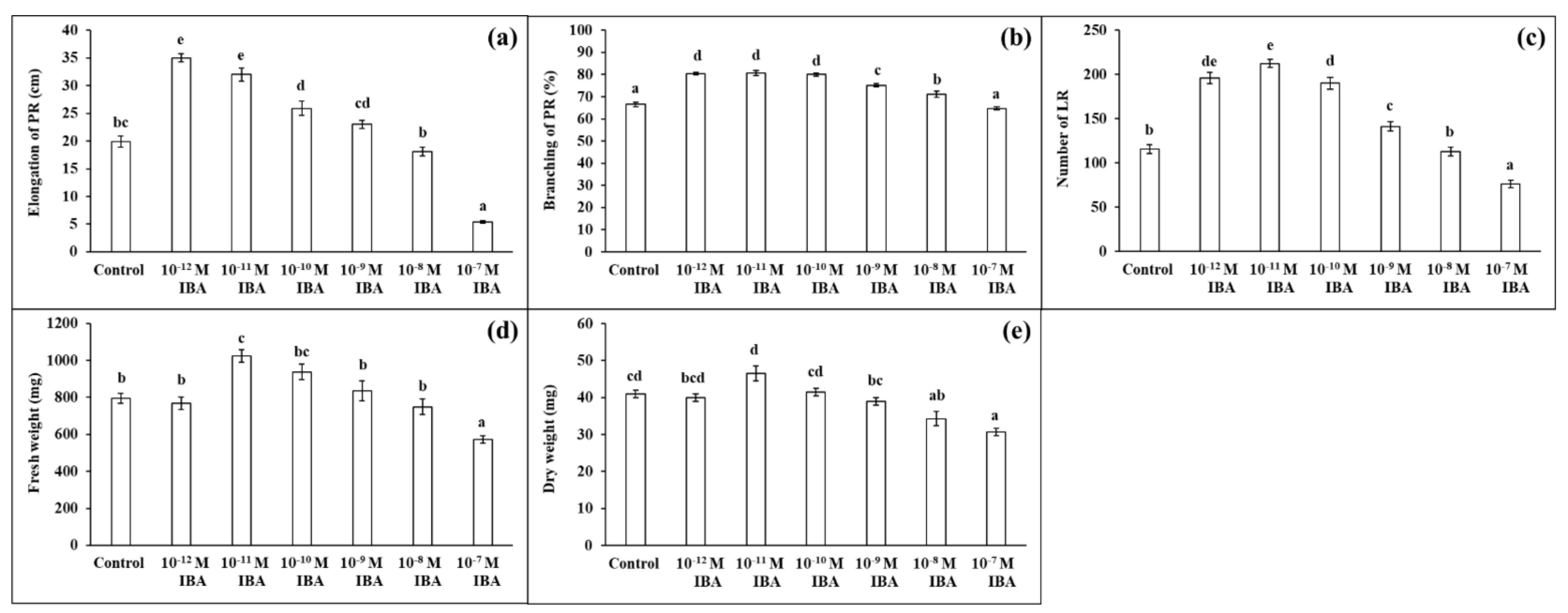

Figure 2. Elongation of PR (a), branching of PR (b), number of LR (c), fresh weight (d), and dry weight (e) of maize roots per one plant cultivated in Hoagland solution (control) and in the same medium supplemented with IBA in various concentrations $\left(10^{-12}-10^{-7} \mathrm{M}\right)$. The data are presented as means \pm standard error $(n=45)$. PR-primary roots; LR—lateral roots. Different letters denote statistically significant differences in the parameters between the treatments at $p<0.05$ according to Tukey test.

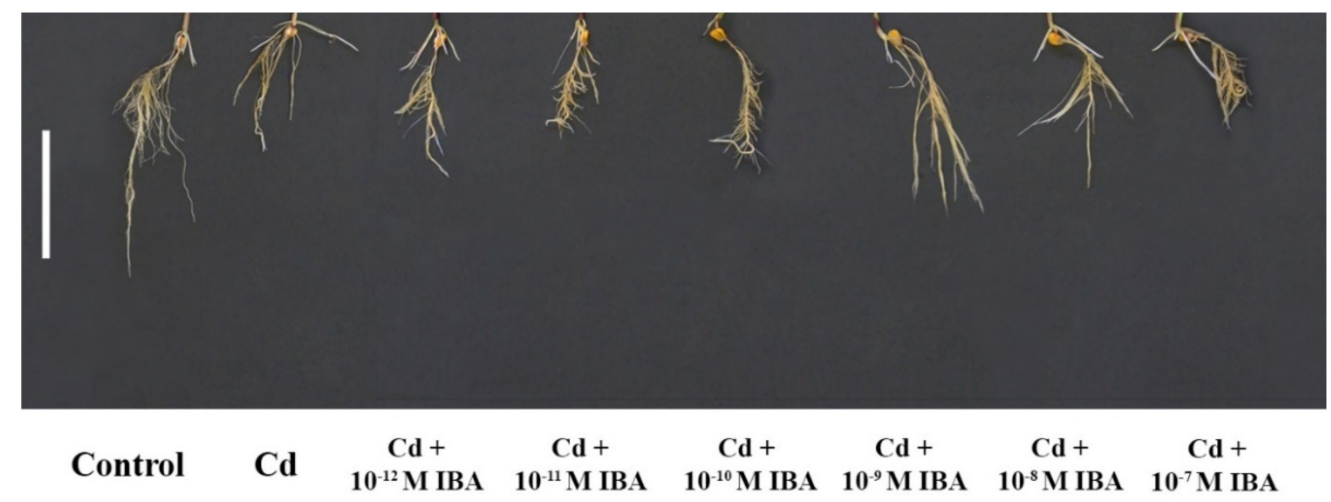

Figure 3. The effects of IBA on the root morphology of plants treated with Cd. Scale bar is $10 \mathrm{~cm}$.

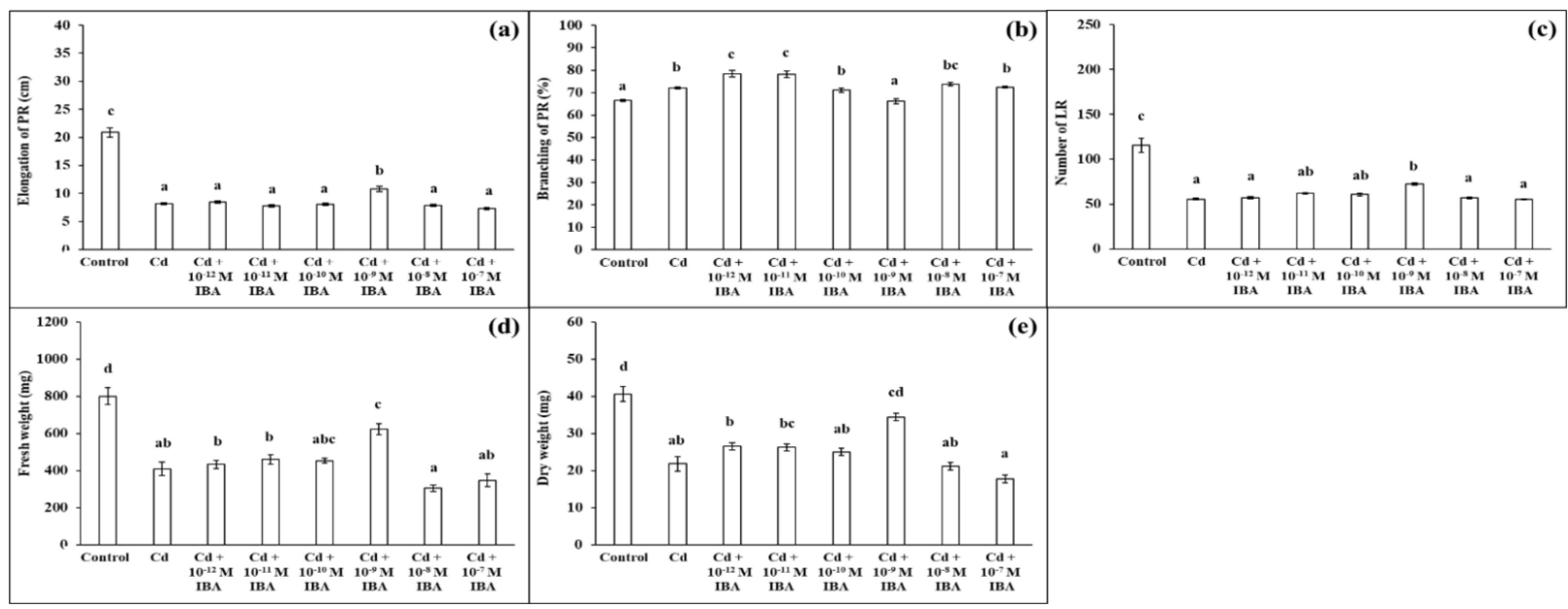

Figure 4. Elongation of PR (a), branching of PR (b), number of LR (c), fresh weight (d), and dry weight (e) of maize roots per one plant cultivated in Hoagland solution (control) and in the same medium supplemented with $\mathrm{Cd}(50 \mathrm{mM})$ or $\mathrm{Cd}$ and IBA in various concentrations $\left(10^{-12}-10^{-7} \mathrm{M}\right)$. The data are presented as means \pm standard error $(n=45)$. PR-primary roots; LR-lateral roots. Different letters denote statistically significant differences in the parameters between the treatments at $p<0.05$ according to Tukey test. 


\subsection{Effects of IBA and $\mathrm{Cd}$ on the Concentrations of $\mathrm{H}_{2} \mathrm{O}_{2}$ and on the Activity of Antioxidant Enzymes}

In our following experiments, we determined the changes in the concentration of $\mathrm{H}_{2} \mathrm{O}_{2}$ and the activities of three antioxidant enzymes (SOD, CAT, APX) in the plants that were treated with two different concentrations of IBA $\left(10^{-11} \mathrm{M}-\right.$ stimulatory and $10^{-7} \mathrm{M}-$ inhibitory), $\mathrm{Cd}$ in a $50 \mu \mathrm{M}$ concentration, and a combination of $\mathrm{Cd}$ and the most effective concentration of IBA $\left(10^{-9} \mathrm{M}\right)$ in alleviating the toxicity of $\mathrm{Cd}\left(\mathrm{Cd}+10^{-9} \mathrm{M}\right.$ IBA treatment).

The highest concentration of $\mathrm{H}_{2} \mathrm{O}_{2}$ was detected in the roots that had the most severe inhibition of root growth when compared to control (Figure 5a). The application of only $\mathrm{Cd}$ resulted in the highest increase in the concentration of $\mathrm{H}_{2} \mathrm{O}_{2}$ (by $136.5 \%$ ), while the $10^{-7} \mathrm{M}$ IBA treatment increased the concentration by $40.6 \%$. Even though the concentration of $\mathrm{H}_{2} \mathrm{O}_{2}$ was reduced considerably in the $\mathrm{Cd}+10^{-9} \mathrm{M}$ IBA treatment (2.5 times lower than in the Cd treatment), it was still higher (by 55.5\%) than in the control. We did not determine any significant differences between the control and the plants treated with other concentrations of IBA.
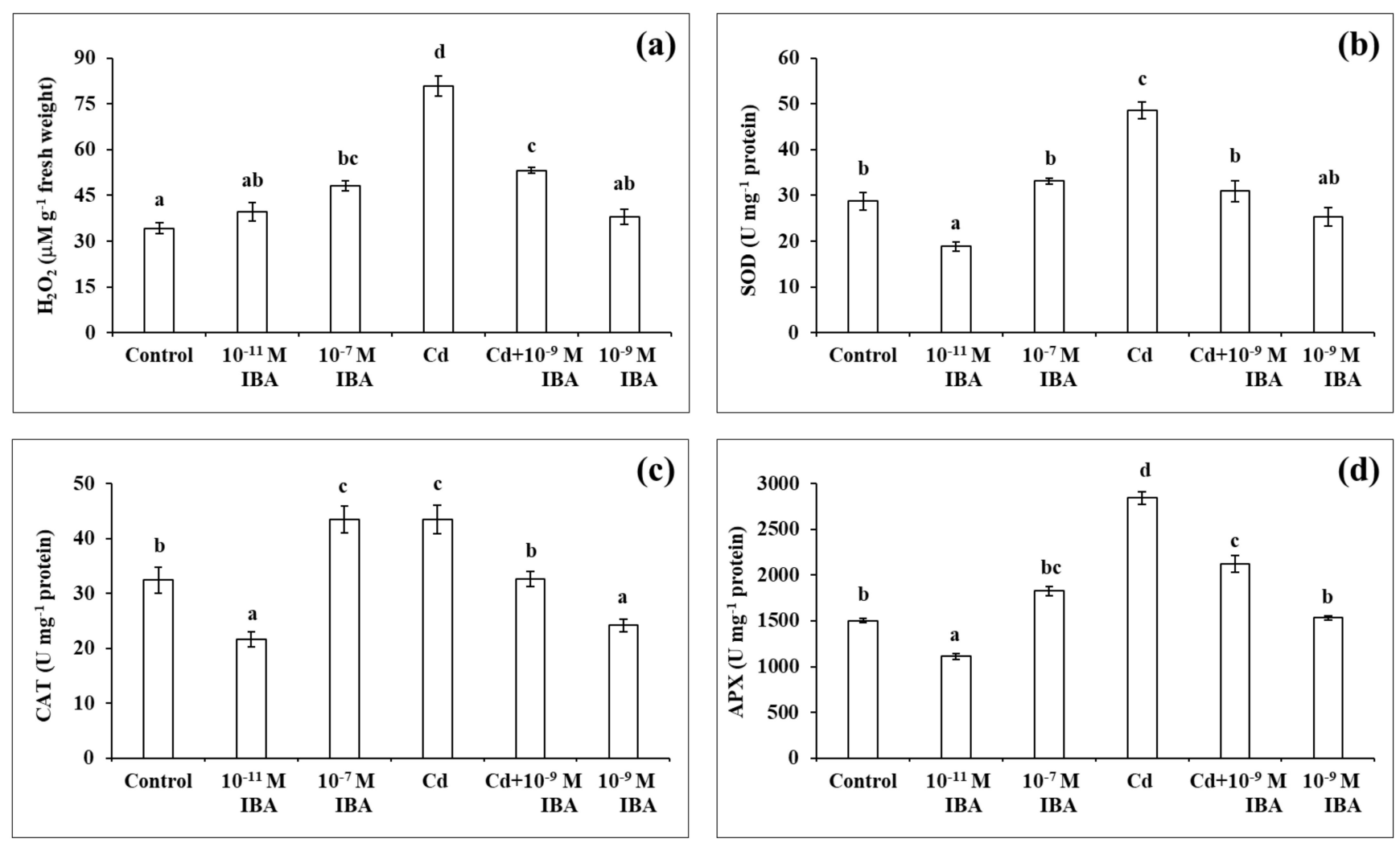

Figure 5. The concentration of $\mathrm{H}_{2} \mathrm{O}_{2}(\mathbf{a})$ and the activities of antioxidant enzymes SOD (b), CAT (c), APX (d) in the maize roots treated without/with $\mathrm{Cd}$. The data are presented as means \pm standard error $(n=15)$. Different letters denote statistically significant differences in the parameters between the treatments at $p<0.05$ according to Tukey test.

In plants treated only with auxin, the highest activity of all the enzymes studied was ascertained in the $10^{-7}$ M IBA treatment (Figure 5b-d). The activity of SOD, CAT, and APX increased by almost $15.3 \%, 34.1 \%$, and $22.0 \%$, respectively, when compared to control. The $10^{-11}$ M IBA treatment resulted in a decrease in the activity of SOD (by $34.2 \%$ ). Our results indicate that the effects of IBA on enzyme activity depend on the concentration used.

In the plants treated with $\mathrm{Cd}$, the highest enzyme activity was observed in the $\mathrm{Cd}$ treatment (Figure $5 \mathrm{~b}-\mathrm{d}$ ). The activity of SOD, CAT, and APX increased by $69.2 \%, 34.2 \%$, and $89.0 \%$, respectively, when compared to the control. The $\mathrm{Cd}+10^{-9} \mathrm{M}$ IBA treatment decreased the activity of SOD (by 36.4\%), CAT (by 25.1\%), and APX (by 25.0\%) when 
compared to the $\mathrm{Cd}$ treatment. The $10^{-9} \mathrm{M}$ IBA treatment decreased only the activity of CAT (by $27.0 \%$ ) compared to the control.

\subsection{Effect of IBA on the Concentration of $\mathrm{Cd}$}

In our study, exogenously applied auxin decreased the concentration of $\mathrm{Cd}$ by $33.0 \%$ in the roots (Figure 6) when compared to the $\mathrm{Cd}$ treatment.

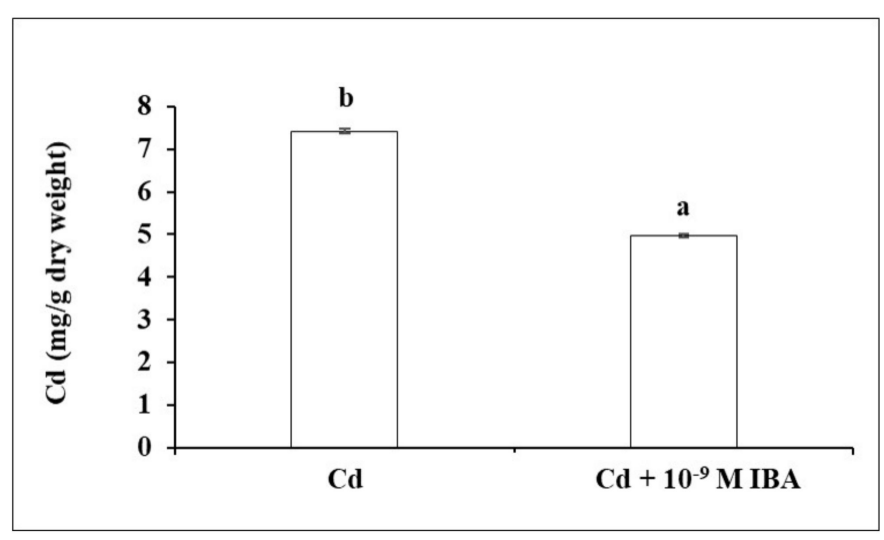

Figure 6. The concentration of $\mathrm{Cd}$ in maize roots of one plant treated without/with IBA. The data are presented as means \pm standard error $(n=5)$. Different letters denote statistically significant differences in the parameters between the treatments at $p<0.05$ according to Student's $t$-test.

\subsection{Effects of IBA and $C d$ on the Concentration of Mineral Nutrients}

The two IBA concentrations $\left(10^{-11}\right.$ and $\left.10^{-7} \mathrm{M}\right)$ caused various changes in the concentrations of macro- and micronutrients in roots (Figures 7 and 8). The $10^{-11} \mathrm{M}$ IBA treatment increased the concentrations of $\mathrm{N}$ (by $8.9 \%$ ), $\mathrm{K}$ (by $14.8 \%$ ), Ca (by $6.1 \%$ ), S (by $9.0 \%$ ), and $\mathrm{Zn}$ (by 5.8\%) and decreased the concentrations of $\mathrm{Mn}$ (by $4.5 \%$ ) and $\mathrm{Cu}$ (by 10.9\%) when compared to control. The $10^{-7} \mathrm{M}$ IBA treatment decreased the concentrations of all nutrients, except for $\mathrm{N}$. The concentrations of macronutrients in the $10^{-7} \mathrm{M}$ IBA treatment decreased in the range between 5.7 and $17.9 \%$, and the concentrations of micronutrients in the range between 5.5 and $36.6 \%$.

The concentrations of all the selected macro- and micronutrients in the maize roots decreased in the $\mathrm{Cd}$ treatment, except $\mathrm{Mg}$ (Figures 7 and 8). The concentration of $\mathrm{Mn}$ was the most affected, as it was decreased by $80.7 \%$ when compared to control (Figure $8 b$ ). Other nutrients that were greatly influenced were $\mathrm{K}, \mathrm{S}, \mathrm{Cu}$, and $\mathrm{Zn}$ (Figure $7 \mathrm{c}$,e and Figure 8c,d). The application of $\mathrm{Cd}$ decreased their concentrations in roots approximately by $40 \%$ when compared to control. The concentrations of N, P, and Ca decreased approximately by $30 \%$ (Figure $7 \mathrm{a}, \mathrm{b}, \mathrm{d}$ ), and the concentration of Fe by $23.1 \%$ (Figure $8 \mathrm{a}$ ). On the other hand, in the combined $\mathrm{Cd}+10^{-9} \mathrm{M}$ IBA treatment the concentrations of all above-mentioned nutrients increased in comparison to $\mathrm{Cd}$ treatment, except for $\mathrm{Mg}$ (Figures $\mathrm{7b}-\mathrm{e}$ and 8). The exogenously applied $10^{-9} \mathrm{M}$ IBA in the $\mathrm{Cd}+10^{-9} \mathrm{M}$ IBA greatly influenced the concentrations of P (by 34.1\%), Cu (by 32.7\%), S (by 20.0\%), and Mn (by 26.8\%) (Figure 7b,e and Figure $8 \mathrm{~b}, \mathrm{~d})$. Other nutrients were increased slightly (N-5.5\%; K-10.8\%; Ca- $11.5 \%$; $\mathrm{Fe}-5.5 \% ; \mathrm{Zn}-5.8 \%$ ) (Figure $7 \mathrm{a}, \mathrm{c}, \mathrm{d}$ and Figure $8 \mathrm{a}, \mathrm{c}$ ). The $10^{-9} \mathrm{M}$ IBA treatment increased the concentration of $\mathrm{K}$ (by 13.2\%) (Figure 7c) and decreased the concentration of $\mathrm{Ca}$ (by $10.5 \%$ ), $\mathrm{Mn}$ (by $16.0 \%$ ), and $\mathrm{Cu}$ (by $16.8 \%$ ) compared to the control (Figures $7 \mathrm{~d}$ and $8 \mathrm{~b}, \mathrm{~d}$ ). 


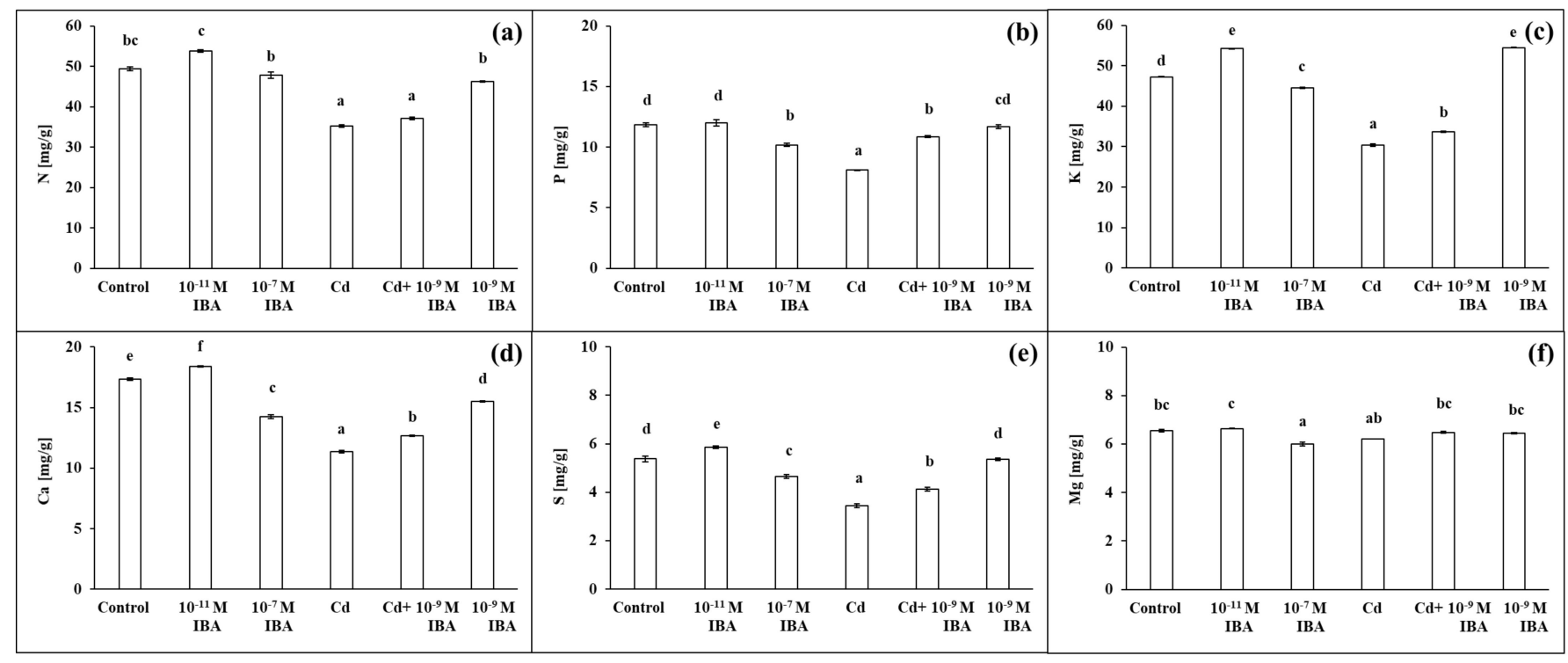

Figure 7. The concentrations of $\mathrm{N}(\mathbf{a}), \mathrm{P}(\mathbf{b}), \mathrm{K}(\mathbf{c}), \mathrm{Ca}(\mathbf{d}), \mathrm{S}(\mathbf{e}), \mathrm{Mg}(\mathbf{f})$ in maize roots treated without/with Cd. The data are presented as means \pm standard error $(n=9)$. Different letters denote statistically significant differences in the parameters between the treatments at $p<0.05$ according to Tukey test.

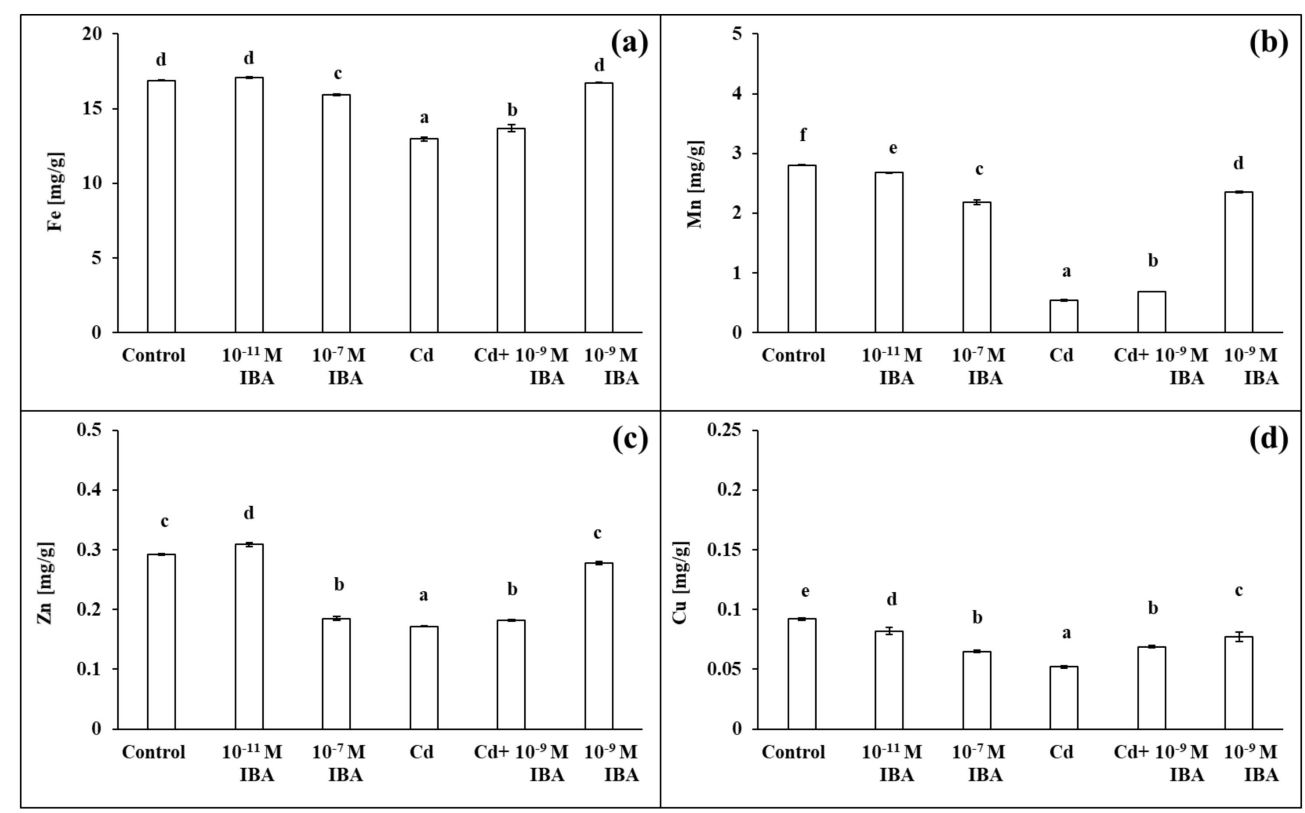

Figure 8. The concentrations of $\mathrm{Fe}(\mathbf{a}), \mathrm{Mn}(\mathbf{b}), \mathrm{Zn}(\mathbf{c}), \mathrm{Cu}(\mathrm{d})$ in maize roots treated without/with $\mathrm{Cd}$. The data are presented as means \pm standard error $(n=9)$. Different letters denote statistically significant differences in the parameters between the treatments at $p<0.05$ according to Tukey test.

\subsection{Data Visualization and Analysis-Relationship among Different Treatments and Observed Parameters}

A heatmap with dendrograms was used to analyze and visualize the data from the study (Figure 9). The dendrograms sort the treatments used in our study (control, $10^{-11} \mathrm{M}$ IBA, $10^{-7} \mathrm{M}$ IBA, $\mathrm{Cd}, \mathrm{Cd}+10^{-9} \mathrm{M}$ IBA, $10^{-9} \mathrm{M}$ IBA), as well as the parameters studied (growth parameters, activity of antioxidant enzymes, concentration of $\mathrm{H}_{2} \mathrm{O}_{2}$ and of nutrients) according to their similarity.

The lateral dendrogram reveals a similarity between the control and the $10^{-9} \mathrm{M}$ IBA treatment. Both the control and the $10^{-9} \mathrm{M}$ IBA treatment are grouped in a cluster together with the $10^{-11} \mathrm{M}$ IBA treatment. The heatmap shows that these treatments had 
mostly positive or no effects on the parameters studied. Another cluster is formed by the treatments: $\mathrm{Cd}, \mathrm{Cd}+10^{-9} \mathrm{M}$ IBA, and $10^{-7} \mathrm{M}$ IBA, which share common features. The coloring clearly shows the increase in the activity of antioxidant enzymes, decrease in the growth parameters, and concentrations of nutrients in comparison with the control. It is noteworthy that there is a closer relationship between $10^{-7} \mathrm{M}$ IBA and $\mathrm{Cd}+10^{-9} \mathrm{M}$ IBA treatments than between the $\mathrm{Cd}+10^{-9} \mathrm{M}$ IBA and $\mathrm{Cd}$ treatments.

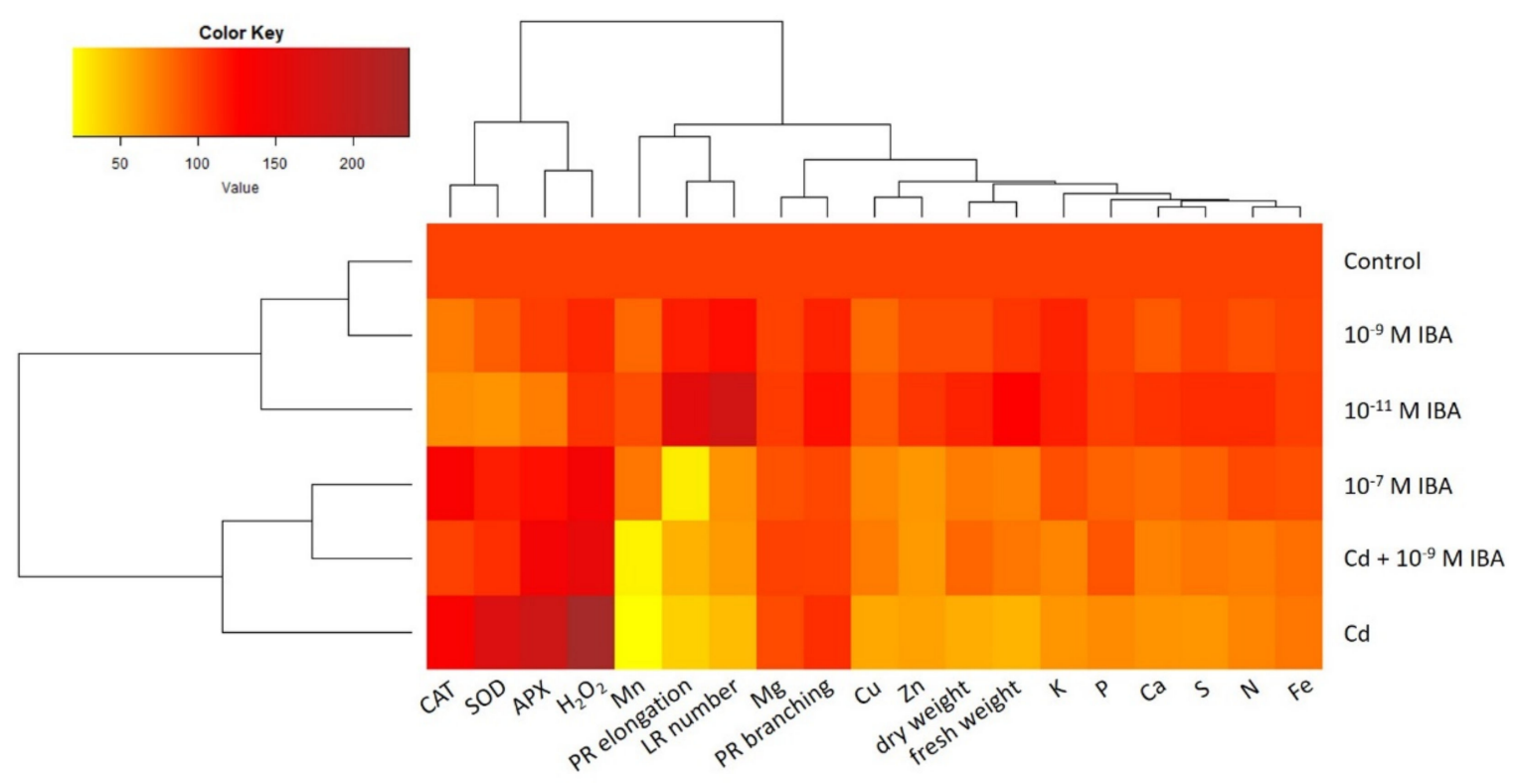

Figure 9. The heatmap analysis of the parameters studied in the treatments: control, $10^{-11} \mathrm{M} \mathrm{IBA}, 10^{-7} \mathrm{M} \mathrm{IBA}, \mathrm{Cd}, \mathrm{Cd}$ $+10^{-9} \mathrm{M}$ IBA, $10^{-9} \mathrm{M}$ IBA. The same color indicates a similar value of the parameter. Every value of every parameter is expressed as a percentage of its corresponding control. PR elongation-elongation of primary root; PR branching-branching of primary root; LR number-number of lateral roots; fresh weight-root fresh weight; dry weight-root dry weight.

Whereas the upper dendrogram of the heatmap indicates the relationships among parameters (Figure 9), the correlation matrix heatmap offers an insight into the correlation among them (Figure 10). The strong positive correlation was detected between the activity of antioxidant enzymes and the concentration of $\mathrm{H}_{2} \mathrm{O}_{2}$ (Figure 10). On the other hand, these parameters correlate negatively with the growth parameters and the concentration of nutrients. A strong correlation was detected among the concentrations of nutrients (with the exception of $\mathrm{Mg}$ ) and biomass (fresh weight and dry weight). The highest Pearson coefficient values (range from 0.8 to 0.96 ) was detected between the biomass (fresh weight and dry weight) and the concentrations of $\mathrm{P}, \mathrm{S}, \mathrm{Ca}, \mathrm{Cu}, \mathrm{K}, \mathrm{Fe}$, and $\mathrm{N}$.

The concentration of $\mathrm{Cd}$ correlates positively with the activity of antioxidant enzymes and the concentration $\mathrm{H}_{2} \mathrm{O}_{2}$. However, the concentration of $\mathrm{Cd}$ had strong negative correlation with nutrients, with the lowest Pearson coefficient values (range from -0.8 to -0.97 ) between the concentration of $\mathrm{Cd}$ and the concentrations of $\mathrm{Fe}, \mathrm{Mn}, \mathrm{N}, \mathrm{K}, \mathrm{S}$, and P. 


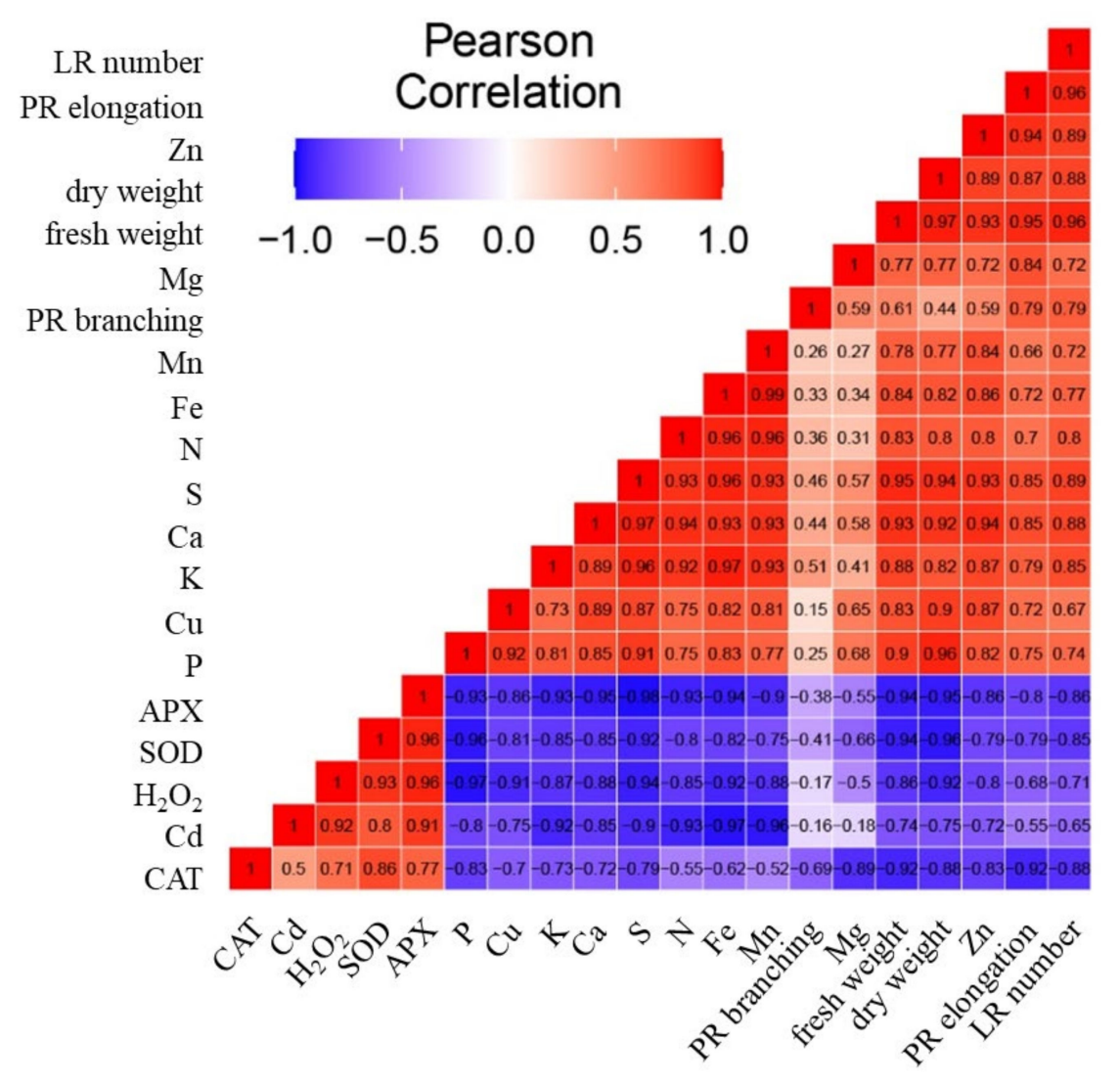

Figure 10. The correlation matrix heatmap shows the values of the Pearson correlation coefficient for all studied parameters, the positive values are in red, negative are in blue. The coefficient ranges from -1 (perfect negative linear relationship) to 1 (perfect positive linear relationship), while the value 0 indicates that there is no relationship between studied variables. The parameters analyzed were the elongation of primary root (PR elongation), PR branching, number of lateral roots (LR number), fresh and dry weight, the activity of enzymes APX, CAT, SOD, the concentration of $\mathrm{H}_{2} \mathrm{O}_{2}$, the concentrations of nutrients $\mathrm{Ca}, \mathrm{K}, \mathrm{Mg}, \mathrm{P}, \mathrm{N}, \mathrm{S}, \mathrm{Fe}, \mathrm{Mn}, \mathrm{Cu}, \mathrm{Zn}$, and the concentration of $\mathrm{Cd}$.

\section{Discussion}

The exogenously applied auxins affect plant growth via endogenous IAA levels by modifying the metabolism of IAA and changing their conjugations with other molecules [23]. The effects of auxins are highly dependent on their concentration. Very low concentrations of exogenous auxins do not cause these modifications. On the other hand, high concentrations of exogenous auxins increased the internal levels of IAA [18], which in turn induced the production of ethylene [24]. High concentrations of ethylene stop plant cell division and slow cell expansion [24] by alkalization of the apoplast, which subsequently decreases the activity of the enzymes responsible for extensibility of the cell wall [25]. Similarly, we observed that a high concentration of IBA $\left(10^{-7} \mathrm{M}\right)$ inhibited maize growth while a low concentration $\left(10^{-11} \mathrm{M}\right)$ had a stimulating effect. Marquez et al. [26] also observed that the habitus of maize roots depend on the type of auxin (IAA, IBA, NAA) and its concentration. Furthermore, new study proved that exogenously applied auxins induce the transverse microtubule organization in plant cells. This step is controlled during the interaction between auxin receptors and the nucleus [27]. The role of microtubules in the cellulose microfibril organization in plant cell walls is also known-transverse microtubules guide the cellulose synthase complexes [28]. It was ascertained that exogenously applied auxin also causes the changes of the cell wall composition of maize roots [29]. Auxin mainly increases the content of cellulose and Klason lignin, components responsible for the strength of the cell walls.

As mentioned above, exogenously applied auxins also alleviate the toxic effects of $\mathrm{Cd}$ [12] and improve the tolerance of plants to stress [30]. The presence of $\mathrm{Cd}$ in plant 
cells has damaging effects on biomolecules, which are important for many physiological processes [31]. Cd in short term, as well as in long term treatments [30,32] decreases the internal level of IAA because it induces IAA degradation by stimulating the activity of IAA-oxidase [12]. Cd also alters the expression of several important auxin biosynthetic and catabolic genes [6]. Thus, the negative effects of $\mathrm{Cd}$ on root growth determined in our experiment might also be connected to these processes. In our study, exogenously applied IBA might have increased the internal level of auxin (previously reduced under the $\mathrm{Cd}$ treatment), which resulted in stimulation of the plant growth. The need to increase the internal level of auxin concentrations in the roots might explain the differences between the most efficient concentration of IBA under non-stress conditions $\left(10^{-11} \mathrm{M}\right)$ and the most efficient concentration of IBA under Cd stress $\left(10^{-9} \mathrm{M}\right)$.

Another toxic effect of $\mathrm{Cd}$ is an alteration of oxidant level of plants through the overproduction of ROS, such as $\mathrm{H}_{2} \mathrm{O}_{2}[33,34]$. The molecules of $\mathrm{H}_{2} \mathrm{O}_{2}$ originate from the process of cell respiration in the mitochondria [35], and the low concentrations of $\mathrm{H}_{2} \mathrm{O}_{2}$ in the root cells act as signaling molecules and regulators of the expression of some genes, and in many aspects resemble phytohormones. A rise in the concentration of $\mathrm{H}_{2} \mathrm{O}_{2}$ damages cell membranes, as well as the processes of respiration, and indicates oxidative stress in plants [12,35]. Oxidative stress occurs in plants exposed to suboptimal growth conditions, e.g., the presence of pollutants.

Auxins have a close association with ROS because these molecules are able to interact with each other [36]. This crosstalk is easily disturbed by changes in the concentrations of auxins or ROS and can result in an impairment of plant growth and development. In our study, the highest concentration of exogenously applied auxin inhibited root growth and increased not only the concentration of $\mathrm{H}_{2} \mathrm{O}_{2}$ but also the activities of APX and CAT. Similarly, Bashri and Prasad [12] observed a higher concentration of $\mathrm{H}_{2} \mathrm{O}_{2}$ and elevated antioxidant enzyme activity after treatment of fenugreek (Trigonella foenum-graecum L.) seedlings with IAA in a concentration that inhibited their growth. Externally applied auxin probably increases the internal level of auxin and subsequently changes the cellular oxidative status of the plant [36], resulting in an increase in ROS production [12]. Hence, the balance between produced-ROS and scavenged-ROS is disturbed and the root cells activate antioxidant enzymes [30]. In our experiment, the stimulatory concentration of IBA $\left(10^{-11} \mathrm{M}\right)$ did not affect the concentration of $\mathrm{H}_{2} \mathrm{O}_{2}$ and decreased the activity of all the enzymes studied. El-Gaied et al. [37] also observed a decrease in SOD, CAT, and TPX gene expression after treatment with IAA and IBA in stimulatory concentrations. On the other hand, Bashri and Prasad [12] observed an increase in the activities of SOD, APX, and CAT despite a reduction in the concentration of $\mathrm{H}_{2} \mathrm{O}_{2}$. The effects of auxin on the activity of antioxidant enzymes depended not only on the concentrations used, but also on the type of the auxin used [37], and the age of the plants [17]. Various activities were also found in different zones of the primary root [38]. The plant species, its phenotype, and its defense mechanisms possibly play an important role in the reaction of antioxidant enzymes to the exogenously applied auxin.

Heavy metals might elevate the levels of $\mathrm{H}_{2} \mathrm{O}_{2}$ in the cells which are linked with the enhanced transport of IAA through auxin transporters as a response to damaged plant cell metabolic pathways. Thus, the $\mathrm{H}_{2} \mathrm{O}_{2}$ levels are directly connected to the stress state of the plants [39]. In our experiments, the presence of $\mathrm{Cd}$ in the maize roots increased the concentration of $\mathrm{H}_{2} \mathrm{O}_{2}$ and subsequently the activity of antioxidant enzymes: SOD, CAT, and APX. The same results were ascertained in plants treated with toxic metals [40]. All three enzymes are the first line of defense against oxidative stress [41] because they are responsible for the maintenance of the steady-state level of superoxide radicals and $\mathrm{H}_{2} \mathrm{O}_{2}$ [41].

In our experiments, the presence of IBA in combination with $\mathrm{Cd}$ decreased the concentration of $\mathrm{H}_{2} \mathrm{O}_{2}$, the activity of SOD, CAT, and APX, when compared to the Cd treatment. The addition of IBA to the medium might have alleviated the toxicity of $\mathrm{Cd}$ in two possible ways. The first way is that IBA could have scavenged the Cd in the cytoplasm. It is 
known that exogenous auxin can act as a chelating agent [42] because auxin occurs in a deprotonated form in the cytoplasm, which has a high affinity to $\mathrm{Cd}$. The second way is that exogenously applied auxin probably supplements the reduced internal levels of auxin, which can affect the level of signaling molecules, for example NO, [14,15] and can be also involved in the signaling pathways of the defense mechanisms [30], for example biosynthesis of metal-binding ligands, phytochelatins, and glutathione [42]. The theory about the auxin signaling pathway in the defense mechanisms is also supported by our results. Exogenously applied IBA decreased the accumulation of $\mathrm{Cd}$ in the roots. Similar effects of stimulatory concentration of IBA on the Cd accumulation in chickweed (Stellaria media L.) and black nightshade (Solanum nigrum L.) roots was observed by Lin et al. [43] and Ran et al. [44]. Natural auxin, IAA, in plants of wheat (Triticum aestioum L.) [45], tamarillo (Cyphomandra betacea Cav.) [46], and tomato (Lycopersicum esculentum Mill.) [13] also decreased $\mathrm{Cd}$ concentration. On the other hand, the synthetic auxin (NAA) increased the concentration of $\mathrm{Cd}$ in arabidopsis (Arabidopsis thaliana L.) [32]. However, the plants grown in hydroponics grow differently from the ones that grow in soil. The delayed maturation of endodermis changed availability of nutrients as well as toxic metals, resulting in a different ion uptake. Still, the usage of hydroponics in basic research ensures constant conditions for plants [22].

Auxin can significantly affect the uptake and the concentrations of some nutrients by affecting proton pump ATPase [47]. In our study, the IBA in the stimulatory concentration $\left(10^{-11} \mathrm{M}\right)$ induced the uptake and accumulation of mineral nutrients $(\mathrm{N}, \mathrm{K}, \mathrm{Ca}, \mathrm{S}, \mathrm{Zn})$ as opposed to the IBA in the inhibitory $\left(10^{-7} \mathrm{M}\right)$ concentration, which decreased their concentrations in roots (except for $\mathrm{N}$ ). The changes in the uptake and accumulation of mineral nutrients in the roots after IAA treatment were also ascertained in pepper (Capsicum annuum L.), alfalfa (Medicago sativa L.), and maize [16,17,47]. In all three plants, they observed significant changes, mainly in the concentrations of $\mathrm{K}, \mathrm{Ca}, \mathrm{Mg}, \mathrm{Mn}$, and $\mathrm{Zn}$. They have not detected any changes in the concentrations of $\mathrm{N}, \mathrm{P}, \mathrm{S}$, and Fe. Auxin probably influences mainly the nutrients that are involved with the growth of roots or the biosynthesis of auxin. The change in the uptake of these nutrients caused by auxins might depend on the plant species and/or duration of auxin exposure. The effects of IBA on the accumulation of mineral nutrients in the roots have not yet been studied.

The present study confirms that $\mathrm{Cd}$ affects the uptake of macro- and micronutrients. We ascertained that $\mathrm{Cd}$ treatment caused an exceptionally high decrease in the concentration of Mn compared to the control. Furthermore, the concentrations of the nutrients $\mathrm{Cu}$ and $\mathrm{Zn}$ were also highly reduced. The reductions in the concentrations of $\mathrm{Mg}$ and Fe were lower. Cd enters the root cell through essential nutrient transporters (for more information, see [48]). Higher concentrations of $\mathrm{Cd}$ in the soil increase the competition with essential nutrients for transporters present at the root surface, thus decreasing their uptake. Our results also show that the $\mathrm{Cd}+$ IBA treatment increased the uptake and accumulation of all nutrients, except for N. Changes in the uptake of mineral nutrients in the stressed plants of alfalfa and maize after IAA treatments, were also studied by López et al. [16] and Wang et al. [17]. López et al. [16] did not determine any significant changes caused by the IAA treatment in the plants stressed by $\mathrm{Pb}$. Wang et al. [17] found that exogenously applied auxin decreased the concentrations of $\mathrm{K}$ and $\mathrm{Mn}$ after long treatment with auxin. The effects of auxin depend not only on the concentration used and the period of the exposure [17] but also on the concentration of the toxic metal [16]. In both mentioned studies, the effects of IAA (in the used concentration) were not linked with growth parameters as opposed to our study, in which the effects of both stimulatory and inhibitory concentrations of IBA are supported by the results of maize growth (Figures 2 and 3).

The heatmap (Figure 9) shows the differences between the effects of $\mathrm{Cd}, \mathrm{Cd}+10^{-9}$ $\mathrm{M}$ IBA, $10^{-11} \mathrm{M}$ and $10^{-7} \mathrm{M}$ IBA treatments. Whereas negative effects of $\mathrm{Cd}$ on growth parameters are associated with the strong increase in the concentration of $\mathrm{H}_{2} \mathrm{O}_{2}$ and activity antioxidant enzymes and with the decrease in the concentrations of micro- and macronutrients; negative effects of $10^{-7} \mathrm{M}$ IBA treatment do not include a significant 
decrease in concentrations of mineral nutrients. The positive effects of $\mathrm{Cd}+10^{-9} \mathrm{M}$ IBA treatment can be linked with increased concentrations of mineral nutrients and decreased activity of antioxidant enzymes. Moreover, the positive effect of $10^{-11} \mathrm{M}$ IBA treatment on the growth parameters and concentrations of nutrients in comparison with the control is clearly visible.

The identification of the most efficient concentration of exogenously applied IBA is a very important result that might be applied in future methods used in the stimulation of plant growth. The usage of natural substances that are termed as biostimulants is quickly becoming a new trend in agriculture. The knowledge that an appropriate concentration of IBA can alleviate the negative effects of toxic elements that are present in the environment, including soils, is crucial for biotechnology. Furthermore, the stimulatory concentration of IBA used both in contaminated and non-contaminated conditions could improve the nutritional value of the plants. However, some portion of the heavy metals that had been uptaken by plants into their root system might leak into the soil and cause secondary pollution [49]. Therefore, basic methods of plant biomass recycling are not applicable in this instance. Some new techniques of dealing with the plant waste residues after phytoremediation seem promising and efficient [50]. For example, Danelli et al. [51] found that anaerobic digestion or combustion (e.g., pyrolysis and gasification) of polluted biomass could be used to produce energy and simultaneously as a remedy for the areas contaminated by $\mathrm{Cu}, \mathrm{Zn}$, and $\mathrm{Cd}$. The production of energy from such material is considered as an environmentally friendly and sustainable process [52]. Furthermore, the application of auxins or other plant growth regulators is also starting to be a widely accepted and acknowledged approach for improving the methods of phytoremediation efficiency in contaminated areas.

\section{Materials and Methods}

\subsection{Plant Material and Cultivation}

Maize grains (hybrid Almansa) were obtained from RWA Slovakia s. r. o. Bratislava, Slovakia. The permits have been obtained for working with plants. We prepared and cultivated the plant material according to our previous research [29]. The maize grains were surface sterilized and imbibed for $3 \mathrm{~h}$ in distilled water in the dark at $25^{\circ} \mathrm{C}$. Then grains germinated for 3 days in wet perlite in the dark at $25^{\circ} \mathrm{C}$. After 3 days, seedlings were transferred to dark containers (3 1/15 plants) which contained Hoagland solution [53], or Hoagland solution supplemented with IBA in concentrations ranging from $10^{-12} \mathrm{M}$ to $10^{-7} \mathrm{M}$, and with/without $\mathrm{Cd}\left(\mathrm{NO}_{3}\right)_{2}$ at a concentration of $50 \mu \mathrm{M}$, at $\mathrm{pH} 6.2$, under controlled conditions (photosynthetic photon flux of $130-140 \mu \mathrm{mol} \mathrm{m}^{-2} \mathrm{~s}^{-1}, 25 / 20{ }^{\circ} \mathrm{C}$ temperature, $16 \mathrm{~h}$ photoperiod, and 70\% humidity) for 10 days. Continuous aeration of solution was given through an air pump by making bubbles. Hoagland solution was changed on the 5th day of cultivation.

\subsection{Measurement of the Growth Parameters}

After 10 days of cultivation, the healthy and undamaged plants were harvested. The elongation of the primary roots (PR) (the difference between the final length and the initial length of PR), the branching of the PR (the length of the branched part of the $\mathrm{PR})$, the number of lateral roots (LR), and the fresh (FW) and dry weight (DW) of roots were determined. All growth parameters were calculated per one root. The roots were frozen individually in liquid nitrogen and stored at $-70{ }^{\circ} \mathrm{C}$ until enzyme extraction. The roots used for elemental analyses were dried individually for $72 \mathrm{~h}$ at $105^{\circ} \mathrm{C}$. For our next analyses, we chose root or mix of roots of one treatment based on their growth parameters (the shortest and longest roots from every treatment were excluded from the mix).

\subsection{Determination of $\mathrm{H}_{2} \mathrm{O}_{2}$}

The hydrogen peroxide $\left(\mathrm{H}_{2} \mathrm{O}_{2}\right)$ concentration was determined according to the modified method of Velikova et al. [54]. The maize roots $(500 \mathrm{mg})$ were homogenized in a cold 
$50 \mathrm{mM}$ sodium phosphate buffer ( $\mathrm{pH} 7.0$ ), then centrifuged at $5300 \mathrm{~g}$ for $10 \mathrm{~min}$ at $4{ }^{\circ} \mathrm{C}$. The supernatant was diluted with $1 \mathrm{mM}$ potassium iodide in the ratio 1:2. The absorbance was measured spectrophotometrically at $390 \mathrm{~nm}$ and the concentration of $\mathrm{H}_{2} \mathrm{O}_{2}$ was calculated based on a standard curve.

\subsection{Determination of Antioxidant Enzymes Activity}

The frozen roots ( $2.7 \mathrm{~g}$ fresh weight) were homogenized in liquid nitrogen and suspended in a $50 \mathrm{mM}$ sodium phosphate buffer $(7 \mathrm{~mL}, \mathrm{pH} 7.8)$, containing $50 \mathrm{mM}$ EDTA and protease inhibitor cocktail tablets (Roche Diagnostics $\mathrm{GmbH}$, Germany). The homogenate was centrifuged at $3800 \mathrm{~g}$ for $30 \mathrm{~min}$ at $4{ }^{\circ} \mathrm{C}$, and a supernatant was used to determine both the activity of the antioxidant enzymes and the concentration of soluble proteins. The latter was determined by the Bradford method, using bovine serum albumin as a standard [55].

The activity of SOD was determined according to Madamanchi et al. [56] and was measured spectrophotometrically at $560 \mathrm{~nm}$. The reaction mixture contained a $50 \mathrm{mM}$ sodium phosphate buffer $(1.8 \mathrm{~mL}, \mathrm{pH} 7.8), 0.15 \mathrm{mM}$ MTT $(150 \mu \mathrm{L}), 13 \mathrm{mM}$ methionine $(600 \mu \mathrm{L}), 1 \mathrm{mM}$ EDTA $(150 \mu \mathrm{L})$, and $2 \mu \mathrm{M}$ riboflavin $(150 \mu \mathrm{L})$. The mixture was placed in sample tubes under fluorescent light $\left(50 \mu \mathrm{mol} \mathrm{m} \mathrm{m}^{-2} \mathrm{~s}^{-1}\right)$ for $15 \mathrm{~min}$. One unit of SOD activity is the amount of proteins causing a $50 \%$ MTT reduction under the light and is expressed as $\mathrm{U} \mathrm{mg}^{-1}$ protein.

The activity of APX was determined according to Nakano and Asada [57] and was measured spectrophotometrically at $290 \mathrm{~nm}$. The reaction mixture contained a $50 \mathrm{mM}$ sodium phosphate buffer ( $\mathrm{pH} 7.0), 1 \mathrm{mM}$ EDTA $(300 \mu \mathrm{L}), 0.5 \mathrm{mM}$ ascorbate $(300 \mu \mathrm{L})$, and $0.1 \mathrm{mM} \mathrm{H}_{2} \mathrm{O}_{2}(300 \mu \mathrm{L})$. One unit of APX is the amount of enzyme required to decompose $1 \mu \mathrm{M}$ of ascorbate per $1 \mathrm{~min}$ and is expressed as $\mathrm{U} \mathrm{mg}^{-1}$ protein.

The activity of CAT was determined according to Hodges et al. [58] and was measured spectrophotometrically at $240 \mathrm{~nm}$. The reaction mixture contained a $50 \mathrm{mM}$ sodium phosphate buffer $(2 \mathrm{~mL}, \mathrm{pH} 7.8)$ and $3 \% \mathrm{H}_{2} \mathrm{O}_{2}(150 \mu \mathrm{L})$. Specific CAT activity was calculated according to Claiborne [59] and expressed as the amount of enzymes required to decompose $1 \mu \mathrm{M}$ of $\mathrm{H}_{2} \mathrm{O}_{2}$ per $1 \mathrm{~min}$ and it was expressed as $\mathrm{U} \mathrm{mg}^{-1}$ protein.

\subsection{Determination of Selected Mineral Nutrients}

Dried maize roots $\left(250 \mathrm{mg}\right.$ ) were dissolved in concentrated $\mathrm{HNO}_{3}(4 \mathrm{~mL})$ and $\mathrm{H}_{2} \mathrm{O}_{2}$ $(2 \mathrm{~mL})$, and the solution was heated at $220{ }^{\circ} \mathrm{C}$ under pressure at 60 bar for $20 \mathrm{~min}$. Measurements of the concentrations of macro- $(\mathrm{Ca}, \mathrm{K}, \mathrm{Mg}, \mathrm{P})$, micronutrients ( $\mathrm{Fe}, \mathrm{Mn}, \mathrm{Cu}$, and $\mathrm{Zn}$ ), and $\mathrm{Cd}$ were carried out by flame atomic absorption spectrometry (AAS Perkin Elmer 1100 and 4100) and by inductively-coupled plasma mass spectrometry (ICP-MS, Thermo iCap Q) at the Institute of Laboratory Research on Geomaterials, Faculty of Natural Sciences, Comenius University in Bratislava, Slovakia. The concentrations of the macronutrients $\mathrm{N}$ and $\mathrm{S}$ were estimated by gas chromatography, using a FLASH 2000 Organic elemental analyzer (CHNS-O) from Thermo Fisher Scientific, Massachusetts, USA, at the Analytical Department, Institute of Chemistry SAS, Bratislava, Slovakia.

\subsection{Data Visualization and Analysis-Heatmap and Correlation Matrix Heatmap}

To create a heatmap and compare the parameters (elongation of PR, branching of PR, number of lateral roots, fresh and dry weight, the activity of enzymes: APX, CAT, $\mathrm{SOD}$, the concentration of $\mathrm{H}_{2} \mathrm{O}_{2}$, the concentrations of nutrients $\mathrm{Ca}, \mathrm{K}, \mathrm{Mg}, \mathrm{P}, \mathrm{N}, \mathrm{S}, \mathrm{Fe}, \mathrm{Mn}$, $\mathrm{Cu}, \mathrm{Zn}$, we normalized the data to the control (expressed every value of every parameter as a percentage of its corresponding control; control $=100 \%$ ). The dendrograms sort the parameters and the treatments (control, IBA $\left(10^{-11} \mathrm{M}\right), \operatorname{IBA}\left(10^{-7} \mathrm{M}\right), \mathrm{Cd}, \mathrm{Cd}+\mathrm{IBA}$, IBA $\left.\left(10^{-9} \mathrm{M}\right)\right)$ according to their similarity. The heatmap was made by using function heatmap.2. From gplots package [60] in R software 4.0.2 (22 June 2020) [61]. The function heatmap. 2 uses Euclidean distance measure to obtain distance matrix and complete linkage method for clustering. 
Correlation matrix heatmap shows the values of Pearson correlation coefficient. The Pearson correlation coefficient is a measure of the strength of the linear relationship between two variables [62]. The correlation matrix was reordered according to the correlation coefficient, which helps to reveal hidden patterns in the matrix. The variables analyzed in the correlation matrix heatmap were elongation of PR, branching of PR, number of lateral roots (LR), fresh and dry weight (FW and DW), the activity of enzymes APX, CAT, SOD, the concentration of $\mathrm{H}_{2} \mathrm{O}_{2}$, the concentrations of nutrients $\mathrm{Ca}, \mathrm{K}, \mathrm{Mg}, \mathrm{P}, \mathrm{N}, \mathrm{S}, \mathrm{Fe}, \mathrm{Mn}, \mathrm{Cu}$, $\mathrm{Zn}$, the concentration of $\mathrm{Cd}$. The correlation matrix heatmap was made using $\mathrm{R}$ software 4.0.2 (22 June 2020) (R Core Team 2020) and ggplot2 package [63].

\subsection{Statistical Analyses}

The data are displayed as mean values \pm standard error (SE) and the experiments were repeated at least 3 times. Statistical analyses followed the analysis of variance (ANOVA) and Tukey test at $p<0.05$ with R software 3.6.3 (29 February 2020). However, for the parameter of the concentration of $\mathrm{Cd}$, a Student's $t$-test was used for the statistical analysis $(p<0.05)$. The number of analyzed values depended on the parameters: 45 values for every treatment (analysis of the growth parameters), 15 for every treatment (analysis of the enzyme activity and the concentration of $\mathrm{H}_{2} \mathrm{O}_{2}$ ), and 9 for every treatment (analysis of the selected mineral nutrients).

\section{Conclusions}

Our results showed that exogenously applied IBA can influence the growth of the maize and alleviate $\mathrm{Cd}$ toxicity. The effect of IBA alone on plants depends on the concentration used, because it may act as an inhibitor or a stimulator of plant growth while influencing the oxidative status of the plant. For better understanding, we used a scheme to summarize the effects of IBA concentrations on maize plants grown in non-stress and stress conditions (Cd stress) (Figure 11).

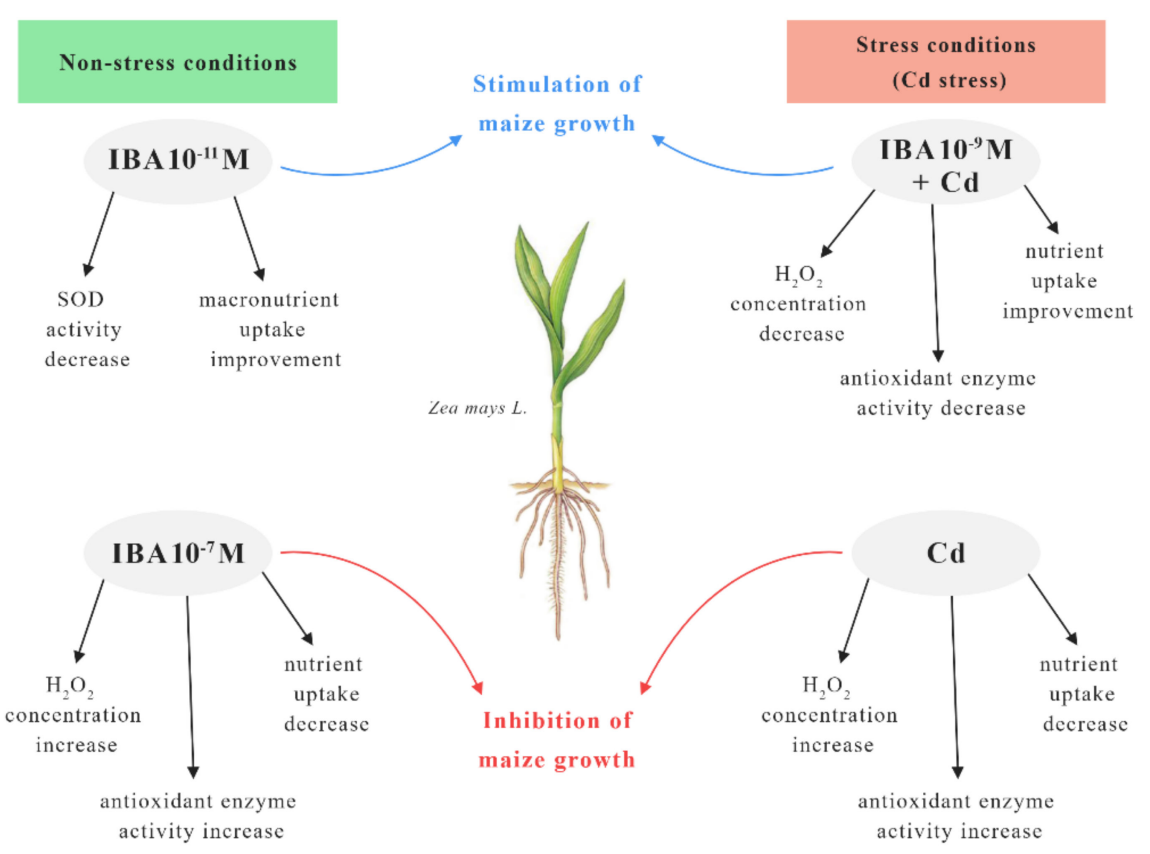

Figure 11. The scheme of the effects of IBA concentrations on maize plants in non-stress and stress (Cd stress) conditions.

In the non-stress conditions, the most effective concentration of IBA in the stimulation of growth was $10^{-11} \mathrm{M}$. This concentration improved the growth mainly by the increase in the nutrient uptake and decrease in the SOD activity when compared to the control. On the other hand, the higher concentration of IBA $\left(10^{-7} \mathrm{M}\right)$ increased the concentration of $\mathrm{H}_{2} \mathrm{O}_{2}$ 
and the activity of antioxidant enzymes which resulted in the inhibited growth. The presence of $\mathrm{Cd}$ in the substrate decreased the concentrations of nutrients in roots and increased the concentration of $\mathrm{H}_{2} \mathrm{O}_{2}$ which resulted in oxidative stress. Cadmium treatment also showed elevated activity of antioxidant enzymes, and the changed physiological status of the plant caused an inhibition of the root growth. However, in stress conditions (Cd stress) IBA in $10^{-9} \mathrm{M}$ concentration best improved the toxic effects of $\mathrm{Cd}$ in plants. Application of IBA in $10^{-9} \mathrm{M}$ decreased the concentration of $\mathrm{H}_{2} \mathrm{O}_{2}$ as well as the activity of antioxidant enzymes in plants and improved the uptake of essential nutrients. All mentioned changes resulted in improved growth of the plants when compared to $\mathrm{Cd}$ treatment.

Author Contributions: K.Š. and Z.V. conceived the present idea and designed the study. K.Š. and E.L. carried out the experiments. K.Š., E.L., K.K., and Z.V. analyzed the data. D.K. made and described a heatmap. K.Š. and Z.V. wrote the manuscript with input from E.L., D.K. and K.K. All authors provided critical comments. All authors have read and agreed to the published version of the manuscript.

Funding: This study was funded by the Scientific Grant Agency of the Ministry of Education of the Slovak Republic and the Academy of Sciences VEGA No. 2/0105/18.

Data Availability Statement: The data presented in this study are available on reasonable request from the corresponding author.

Conflicts of Interest: The authors declare no conflict of interest.

\section{References}

1. Tognetti, V.B.; Mühlenbock, P.; van Breusegem, F. Stress homeostasis-The redox and auxin perspective. Plant Cell Environ. 2012, 35, 321-333. [CrossRef] [PubMed]

2. Depuydt, S.; Hardtke, C.S. Hormone signalling crosstalk in plant growth. Curr. Biol. 2011, 21, 365-373. [CrossRef] [PubMed]

3. Garg, N.; Manchanda, G. ROS generation in plants: Boon or bane? Plant Biosyst. 2009, 143, 81-96. [CrossRef]

4. Ahmad, P.; Tripathi, D.K.; Deshmukh, R.; Singh, V.P.; Corpas, F.J. Revisiting the role of ROS and RNS in plants under changing environment. Environ. Exp. Bot. 2019, 161, 1-3. [CrossRef]

5. Kohli, S.K.; Khanna, K.; Bhardwaj, R.; Abd Allah, E.F.; Ahmad, P.; Corpas, F.J. Assessment of Subcellular ROS and NO Metabolism in Higher Plants: Multifunctional Signaling Molecules. Antioxidants 2019, 8, 641. [CrossRef]

6. Asgher, M.; Khan, M.I.R.; Anjum, N.A.; Khan, N.A. Minimising toxicity of cadmium in plants-Role of plant growth regulators. Protoplasma 2015, 252, 399-413. [CrossRef] [PubMed]

7. Jan, S.; Alyemeni, M.N.; Wijaya, L.; Alam, P.; Siddique, K.H.; Ahmad, P. Interactive effect of 24-epibrassinolide and silicon alleviates cadmium stress via the modulation of antioxidant defense and glyoxalase systems and macronutrient content in Pisum sativum L. seedlings. BMC Plant Biol. 2018, 18, 146. [CrossRef]

8. Hernandez-Baranda, Y.; Rodriguez-Hernandez, P.; Pena-Icart, M.; Merino-Hernandez, Y.; Cartya-Rubio, O. Toxicity of Cadmium in plants and strategies to reduce its effects. Case study: The tomato. Cultiv. Trop. 2019, 40, e10. [CrossRef]

9. Wagner, G.J. Accumulation of cadmium in crop plants and its consequences to human health. In Advances in Agronomy; Wagner, G.J., Ed.; Elsevier Academic Press: San Diego, CA, USA, 1993; Volume 51, pp. 173-212. [CrossRef]

10. Clemens, A.; Aarts, M.G.; Thomine, S.; Verbuggen, N. Plant science: The key to prevent slow cadmium poisoning. Trend Plant Sci. 2013, 18, 92-99. [CrossRef]

11. Järup, L.; Åkesson, A. Current status of cadmium as an environmental health problem. Toxicol. Appl. Pharmacol. 2009, 238, 201-208. [CrossRef]

12. Bashri, G.; Prasad, S.M. Exogenous IAA differentially affects growth, oxidative stress and antioxidants system in Cd stressed Trigonella foenum-graecum L. seedlings: Toxicity alleviation by up-regulation of ascorbate-glutathione cycle. Ecotoxicol. Environ. Saf. 2016, 132, 329-338. [CrossRef]

13. Khan, M.Y.; Prakash, V.; Yadav, V.; Chauhan, D.K.; Prasad, S.M.; Ramawat, N.; Singh, V.P.; Tripathi, D.K.; Sharma, S. Regulation of cadmium toxicity in roots of tomato by indole acetic acid with special emphasis on reactive oxygen species production and their scavenging. Plant Physiol. Biochem. 2019, 142, 193-201. [CrossRef]

14. Demecsová, L.; Zelinová, V.; Liptáková, L'.; Valentovičová, K.; Tamás, L. Indole-3-butyric acid priming reduced cadmium toxicity in barley root tip via NO genereation and enhanced glutathione peroxidase activity. Planta 2020, 252, 46-62. [CrossRef]

15. Piacentini, D.; Rovere, F.D.; Sofo, A.; Fattorini, L.; Falasca, G.; Altamura, M.M. Nitric oxide cooperates with auxin to mitigate the alterations in the root system caused by cadmium and arsenic. Front. Plant Sci. 2020, 11, 1182-1198. [CrossRef]

16. López, M.L.; Peralta-Videa, J.R.; Benitez, T.; Duarte-Gardea, M.; Gardea-Torresdey, J.L. Effects of lead, EDTA, and IAA on nutrient uptake by alfalfa plants. J. Plant Nutr. 2007, 30, 1247-1261. [CrossRef]

17. Wang, H.H.; Shan, X.Q.; Wen, B.; Owens, G.; Fang, J.; Zhang, S.Z. Effect of indole-3-acetic acid on lead accumulation in maize (Zea mays L.) seedlings and the relevant antioxidant response. Environ. Exp. Bot. 2007, 61, 246-253. [CrossRef] 
18. Nordström, A.C.; Jacobs, F.A.; Efiasson, L. Effect of exogenous indole-3-acetic acid and indole-3-butyric acid on internal levels of the respective auxins and their conjugation with aspartic acid during adventitious root formation in pea cuttings. Plant Physiol. 1991, 96, 856-861. [CrossRef]

19. Kaczmarek, D.K.; Parus, A.; Lozynsko, M.; Pernak, J. Use of ammonium salts or binary mixtures derived from amino acids, glycine betaine, choline and indole-3-butyric ciad as plant regulators. RSC Adv. 2020, 10, 43058. [CrossRef]

20. Kaczmarek, D.K.; Kleiber, T.; Wenping, L.; Niemczak, M.; Chrzanowski, L.; Pernak, J. Transformation of indole-3-butyric acid into ionic liquids as a sustainable strategy leading to highy efficient plant growth stimulators. ACS Sustain. Chem. Eng. 2020, 8 , 1591-1598. [CrossRef]

21. Jones, J.B. Complet Guide for Growing Plants Hydroponically, 1st ed.; CRC Press: Boca Raton, FL, USA, 2014.

22. Redjala, T.; Zelko, I.; Sterckeman, T.; Legue, V.; Lux, A. Relationship between root structure and root cadmium uptake in maize. Envir. Exper. Bot. 2011, 71, 241-247. [CrossRef]

23. Štefančič, M.; Štampar, F.; Veberič, R.; Osterc, G. The levels of IAA, IAAsp and some phenolics in cherry rootstock 'GiSelA 5' leafy cuttings pretreated with IAA and IBA. Sci. Hortic. 2007, 112, 399-405. [CrossRef]

24. Çakmakçı, R.; Mosber, G.; Milton, A.H.; Alatürk, F.; Ali, B. The Effect of Auxin and Auxin-Producing Bacteria on the Growth, Essential Oil Yield, and Composition in Medicinal and Aromatic Plants. Curr. Microbiol. 2020, 77, 564-577. [CrossRef]

25. Majda, M.; Robert, S. The role of auxin in cell wall expansion. Int. J. Mol. Sci. 2018, 19, 951. [CrossRef]

26. Marquez, G.; Alarcon, M.V.; Salguero, J. Differential responses of primary and lateral roots to indole-3-acetic acid, indole-3-butyric acid, and 1-naphthaleneacetic acid in maize seedlings. Biol. Plant 2016, 60, 367-375. [CrossRef]

27. True, J.H.; Shaw, S.L. Exogenous auxin induces transverse microtubule arrays throught transporter Transport inhibitor response1/auxin signaling f-box receptors. Plant Physiol. 2020, 182, 892-907. [CrossRef]

28. Wasteneys, G.O. Progress in understanding the role of microtubules in plan cells. Curr. Opin. Plant Biol. 2004, 7, 651-660. [CrossRef]

29. Šípošová, K.; Kollárová, K.; Lišková, D.; Vivodová, Z. The effects of IBA on the composition of maize root cell walls. J. Plant Physiol. 2019, 239, 10-17. [CrossRef]

30. Demecsová, L.; Tamás, L. Reactive oxygen species, auxin and nitric oxide in metal-stressed roots: Toxicity or defence. BioMetals 2019, 32, 717-744. [CrossRef]

31. Rizwan, M.; Ali, S.; Abbas, T.; Zia-ur-Rehman, M.; Hannan, F.; Keller, C.; Al-Wabel, M.I.; Ok, Y.S. Cadmium minimization in wheat: A critical review. Ecotoxicol. Environ. Saf. 2016, 130, 43-53. [CrossRef]

32. Zhu, X.F.; Wang, Z.W.; Dong, F.; Lei, G.J.; Shi, Y.Z.; Li, G.X.; Zheng, S.J. Exogenous auxin alleviates cadmium toxicity in Arabidopsis thaliana by stimulating synthesis of hemicellulose 1 and increasing the cadmium fixation capacity of root cell walls. J. Hazard. Mater. 2013, 263, 398-403. [CrossRef]

33. Choudhury, S.; Panda, S.K. Role of salicylic acid in regulating cadmium induced oxidative stress in Oryza sativa L. roots. Bulg. J. Plant Physiol. 2004, 30, 95-110.

34. Hasanuzzaman, M.; Hossain, M.A.; Fujita, M. Exogenous selenium pretreatment protects rapeseed seedlings from cadmiuminduced oxidative stress by upregulating antioxidant defense and methylglyoxal detoxification systems. Biol. Trace Elem. Res. 2012, 149, 249-261. [CrossRef] [PubMed]

35. Černý, M.; Habánová, H.; Berka, M.; Luklová, M.; Brzobohatý, B. Hydrogen peroxide: Its role in plant biology and crosstalk with signalling networks. Int. J. Mol. Sci. 2018, 19, 2812. [CrossRef] [PubMed]

36. Mishra, S.; Srivastava, V.; Mehrotra, S.; Quadri, S.N. The regulation of plant development: Cross-talk of reactive oxygen species and plant hormones. In Reactive Oxygen Species in Plants: Boon or Bane-Revisiting the Role of ROS; Singh, V.P., Sing, S., Tripathi, D.K., Prasad, S.M., Eds.; Wiley: Hoboken, NJ, USA, 2017; pp. 243-260.

37. El-Gaied, L.F.; Abu El-Heba, G.A.; El-Sherif, N.A. Effect of growth hormones on some antioxidant parameters and gene expression in tomato. GM Crops Food 2013, 4, 67-73. [CrossRef]

38. Tyburski, J.; Dunajska, K.; Mazurek, P.; Piotrowska, B.; Tretyn, A. Exogenous auxin regulates $\mathrm{H}_{2} \mathrm{O}_{2}$ metabolism in roots of tomato (Lycopersicon esculentum Mill.) seedlings affecting the expression and activity of CuZn-superoxide dismutase, catalase, and peroxidase. Acta Physiol. Plant. 2009, 31, 249-260. [CrossRef]

39. Saini, S.; Kaur, N.; Pati, P.K. Phytohormones: Key players in the modulation of heavy metal stress tolernace in plants. Ecotoxicol. Environ. Saf. 2021, 223, 112578. [CrossRef]

40. Singh, S.; Singh, S.; Ramachandran, V.; Eapen, S. Copper tolerance and response of antioxidative enzymes in axenically grown Brassica juncea (L.) plants. Ecotoxicol. Environ. Saf. 2010, 73, 1975-1981. [CrossRef]

41. Mittler, R. Oxidative stress, antioxidants and stress tolerance. Trends Plant Sci. 2002, 7, 405-410. [CrossRef]

42. Singh, H.; Bhat, J.A.; Singh, V.P.; Corpas, F.J.; Yadav, S.R. Auxin metabolic network regulates the plant response to metalloids stress. J. Hazard. Mater. 2021, 405, 124250. [CrossRef]

43. Lin, L.; Ma, Q.; Wang, J.; Lv, X.; Liao, M.; Xia, H.; Chen, S.; Lai, Y.; Chen, C.; Wang, X.; et al. Effects of indole-3-butyric acid (IBA) on growth and cadmium accumulation in the accumulator plant Stellaria Media Environ. Prog. Sustain. Energy 2018, $37,733-737$. [CrossRef]

44. Ran, J.; Zheng, W.; Wang, H.; Wang, H.; Li, Q. Indole-3-acetic acid promotes cadmium (Cd) accumulation in a Cd hyperaccumulator and a non-hyperaccumulator by different physiological responses. Ecotoxicol. Environ. Saf. 2020, $191,110213$. [CrossRef] 
45. Agami, R.A.; Mohamed, G.F. Exogenous treatment with indole-3-acetic acid and salicylic acid alleviates cadmium toxicity in wheat seedlings. Ecotoxicol. Environ. Saf. 2013, 94, 164-171. [CrossRef]

46. Li, Z.; Zhu, J.; Wang, Y.; Lin, L. Effects of exogenous indole acetic acid on growth and cadmium accumulation of Cyphomandra betacea seedlings. Int. J. Environ. Anal. Chem. 2020. [CrossRef]

47. San-Francisco, S.; Houdusse, F.; Zamarreno, A.M.; Garnica, M.; Casanova, E.; Garcia-Mina, J.M. Effects of IAA and IAA precursors on the development, mineral nutrition, IAA content and free polyamine content of pepper plants cultivated in hydroponic conditions. Sci. Hortic. 2005, 106, 38-52. [CrossRef]

48. Huang, X.; Duan, S.; Wu, Q.; Yu, M.; Shabala, S. Reducing cadmium accumulation in plants: Structure-function relations and tissue-specific operation of transporters in the spotlight. Plants 2020, 9, 223. [CrossRef]

49. Huang, D.; Wang, R.; Liu, Y.; Zeng, G.; Lai, C.; Xu, P.; Lu, B.; Xu, J.; Wang, C.; Huang, C. Application of molecularly imprinted polymers in wastewater treatment: A review. Environ. Sci. Pollut. Res. 2015, 22, 936-977. [CrossRef]

50. Keller, C.; Ludwig, C.; Davoli, C.; Wochele, J. Thermal treatment of metal-enriched biomass produced from heavy metal phytoextraction. Environ. Sci. Technol. 2005, 39, 3359-3367. [CrossRef]

51. Danelli, T.; Sepulcri, A.; Masetti, G.; Colombo, F.; Sangiorgio, S.; Cassani, E.; Anelli, S.; Adani, F.; Pilu, R. Arundo donax L. biomass production in a polluted area: Effects of two harvest timings on heavy metals uptake. Appl. Sci. 2021, 11, 1147. [CrossRef]

52. Edgar, V.-N.; Fabián, F.-L.; Mario, P.-C.J.; Ileana, V.-R. Coupling plant biomass derived from phytoremediation of potential toxic-metal-polluted soils to bioenergy production and high-value by-products-A review. Appl. Sci. 2021, 11, 2982. [CrossRef]

53. Hoagland, D.R.; Arnin, D.I. The water-culture method growing plants without soil. Circ. Calif. Agric. Exp. Stn. 1950, 347, 1-39.

54. Velikova, V.; Yordanov, I.; Edreva, A. Oxidative stress and some antioxidant systems in acid rain-treated bean plants protective role of exogenous polyamines. Plant Sci. 2000, 151, 59-66. [CrossRef]

55. Bradford, M.M. A rapid and sensitive method for the quantitation of microgram quantities of protein utilizing the principle of protein-dye binding. Anal. Biochem. 1976, 72, 248-254. [CrossRef]

56. Madamanchi, N.R.; Donahue, J.L.; Cramer, C.L.; Alscher, R.G.; Pedersen, K. Differential response of Cu, Zn superoxide dismutases in two pea cultivars during a short-term exposure to sulfur dioxide. Plant Mol. Biol. 1994, 26, 95-103. [CrossRef]

57. Nakano, Y.; Asada, K. Hydrogen peroxide is scavenged by ascorbate-specific peroxidase in spinach chloroplasts. Plant Cell Physiol. 1981, 22, 867-880. [CrossRef]

58. Hodges, D.M.; Andrews, C.J.; Johnson, D.A.; Hamilton, R.I. Antioxidant enzyme responses to chilling stress in differentially sensitive inbred maize lines. J. Exp. Bot. 1997, 48, 1105-1113. [CrossRef]

59. Claiborne, A. Catalase activity. In Handbook of Methods for Oxygen Radical Research, 1st ed.; Greenwald, R.A., Ed.; CRC Press: Boca Raton, FL, USA, 1985; pp. 283-284.

60. Warnes, G.R.; Bolker, B.; Bonebakker, L.; Gentleman, R.; Huber, W.; Liaw, A.; Lumley, T.; Maechler, M.; Magnusson, A.; Moeller, S.; et al. gplots: Various R Programming Tools for Plotting Data. R Package Version 3.0.4. Available online: https: / /CRAN.R-project.org/package=gplots (accessed on 7 September 2020).

61. R Core Team. R: A Language and Environment for Statistical Computing; R Foundation for Statistical Computing: Vienna, Austria; Available online: https:/ / www.r-project.org/ (accessed on 22 June 2020).

62. Schober, P.; Boer, C.; Schwarte, L.A. Correlation coefficients: Appropriate use and interpretation. Anesth. Analg. 2018, 126, 1763-1768. [CrossRef]

63. Wickham, H. Ggplot2: Elegant Graphics for Data Analysis; Springer: New York, NY, USA, 2016. 